\title{
Imperialist Ideology and Kurtz in Heart of Darkness and Apocalypse Now
}

\author{
Shuting Sun $^{1}$ \\ ${ }^{1}$ English Department, North China Electric Power University, Baoding, China \\ Correspondence: Shuting Sun, English Department, North China Electric Power University, North District of \\ Baoding City, Hebei Province, 071003, China. Tel: 86-312-752-5154. E-mail: sunsting@ncepu.edu.cn
}

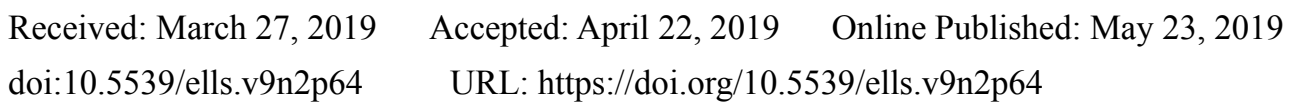

\begin{abstract}
This article will argue that the tragedy of both Kurtzes is that they are trapped in the perverse logic of the ideology of imperialism. The ideology of imperialism assumes the absolute superiority of the oppressor. It is self-contradictory because it is based upon classifying the oppressed as morally inferior, but maintaining imperialism requires systematic barbarity, which morally degrades the imperialist. The historical response of successful imperialists to this has been a special kind of hypocrisy embodied in an attempt at creating distance between actor and act, perpetrator and victim. This article will make the case that both Kurtzes are destroyed by their moral integrity. They honestly admit their depravity to themselves. This grants them great power in facilitating imperial strategic aims but forces them to acknowledge the lie at the heart of imperialist ideology that legitimized the strategy, rendering their acts purposeless. The honesty of their conduct undermines the imperialist ideology. The honesty of their undertakings causes the managers to increasingly perceive Kurtz as a threat and identify him with the 'savages' they are supposed to be 'civilizing'. Kurtz challenges the hypocrisy of the ideology of imperialism precisely insofar as he helps it achieve its true aims.
\end{abstract}

Keywords: Heart of Darkness, Apocalypse Now, imperialism, ideology, Kurtz

\section{Introduction}

This article is a character comparison of Mr. Kurtz in Heart of Darkness and Colonel Kurtz in Apocalypse Now. Francis Ford Coppola's Apocalypse Now is clearly modeled upon Joseph Conrad's Heart of Darkness, particularly in its portrayal of the extraordinary and mysterious Kurtz. This article explains their madness as arising from the same choice they make in response to an honest recognition of the dichotomy at the heart of imperialist ideology. Both Kurtzes realize that imperialist ideology is dishonest in its claims to the moral superiority of the colonists and the project of the improvement of the natives, a mask of greed and exploitation. The Kurtzes choose to pursue the imperialist strategy directly; Mr. Kurtz sets up a base alone in the deepest part of uncharted territory where he becomes enmeshed in tribal politics and warfare of people not yet under company control, Colonel Kurtz raises a guerrilla army of Montagnard tribesmen, executing the war on his own against orders from central command deep behind enemy lines. When Kurtz renounces the pretense of the moral superiority of the imperialist and his alleged noble ends Kurtz is no longer encumbered by the fear of action that comes with this hypocrisy. This improves performance in terms of imperialist strategy. But the admission of pure exploitation/pure power politics delegitimizes the whole imperialist project, which turns the one-time idealist Kurtz into a nihilist. His single-minded obsession with the task at hand empowers him at the expense of hypocrisy, which alienates him from those who sent him out there.

There is a vast body of secondary literature on Joseph Conrad's novella Heart of Darkness. They range from acclaiming the text as an artistic masterpiece (Watts, 2008, pp. 19-37) to condemning it as racist (Achebe, 2016). That there has been such a controversy of interpretation probably indicates that Terry Eagleton was close to the truth in arguing that it is a fundamentally ambiguous piece of work (Eagleton, 1976, p. 135). While Eagleton sees this as the weakness of the author failing to commit, this article wants to argue that this ambiguity is an aesthetic truth of the work, its great strength when read as an anti-imperialist work. This article shares Hillis Miller's assessment of Heart of Darkness as "an exemplary revelation of the ideology of capitalist imperialism" (Miller, 2008, p. 137). As such it functions as a criticism. Imperialist ideology is depicted as the ideology of 
overcoming the darkness of the mystery of the other, outside of one's borders, by imposing one's will upon it. This is based upon imposing mystery upon the unknown through forcing muteness upon the subjugated and refusing to listen when he/she speaks. Imperialism is strangely dependent upon the darkness. It needs to fail to comprehend what it is doing, partly because of its depravity, but also partly because once it admits that its victims can speak the mystery vanishes through listening without violence. Chinua Achebe's criticism of Heart of Darkness as a racist work is misplaced because the work is a depiction of a racist ideology. Achebe has mistaken the depiction of racist imperialism, which is tortured and brought to crisis in Heart of Darkness, with its advocacy. I therefore concur with Leonard Kibera who says "I study Heart of Darkness as an examination of the West itself and not as a comment on Africa" (Hawkins, 1982, p. 64). It is not about Africa. It is about what the imperialist ideology has made of Africa. Scholarly attention to Francis Ford Coppola's Apocalypse Now has been mainly focused on comparisons with Heart of Darkness. It has been criticized as imperialist in the ease with which it exports a story about Africa to a story about the Vietnam War. Mr. Kurtz's "small-scale, low-tech atrocities committed in the company of his 'primitive' henchmen ... become the real horror [of Vietnam], while the massive napalming [by the United States] is made ethically peripheral, that is, ethically downstream from the true heart of darkness" (Nixon, 1992, p. 97). This criticism is unfair to the novel and the film. First, it should be noted that while US army atrocities are depicted in extravagant detail, Kurtz's own are merely mentioned. This criticism also grotesquely underplays the horror of the Congo Free State of which Conrad's Kurtz had real historical prototypes and to which he was raising awareness (modern estimates have the death toll at approximately ten million murdered and starved with countless others maimed and brutalized). The horror of the Vietnam War was indeed comparable to the horror of slavery in Africa. This reading is also blind to the stylistic devices of Heart of Darkness that anticipate cinematic presentation (Cahir, 1992). It further repeats Achebe's error of mistaking the depiction of the darkness of the ideology of imperialism's projection and the depiction of its own blindness to itself for an alleged darkness really existing in the guise of the mysterious Kurtz, mysterious only because he sees and hears imperialism for what it is and not the sham. Later it will be explained that insofar as Kurtz represents the heart of darkness it is only insofar as he holds a mirror up to the imperialist ideology itself. Apocalypse Now is a depiction of imperialist ideology, which is unchanged by time and place, however different Vietnam is from Africa. The muteness of imperialism's victims is made homogenous, not because these victims really are homogenous but because they have to be perceived that way in imperialist ideology. Apocalypse Now is not racist in depicting the same failure to recognize the other as Heart of Darkness in a different context. It is anti-imperialist in its identification of that same imperialist ideology alive and well decades after the formal end of the colonial era. When Conrad wrote Heart of Darkness criticism of the imperialist project in Africa in the west was only beginning. When Coppola made his film Apocalypse Now nineteenth century imperialism and slavery were widely condemned. So, when Coppola identified the same mentality in America's prosecution of the Vietnam War as was in the imperialist ideology in the African colonies this was automatically to invite radical criticism of it. It is not racist to depict imperialist ideology as a kind of madness blind to its cruelty and deaf to its victims. The imperialist hypocrisy characterizing the ideology of the American occupation of Vietnam that Coppola's Kurtz abhorred 'tied in nicely with Conrad's emphasis on the hypocrisy of the European civilizing mission in the Belgian Congo' (Childs, 2013). This article's comparison of the two Kurtzes is not new in identifying the link between them in their disgust with the lies of empire. The article is new in the way that analysis Kurtz's challenge to imperialist hypocrisy as exposing it to be a response to a kind of dichotomy inherent in the imperialist ideology.

Section 2 of this article will explain the dichotomy of imperialist ideology. Section 3 will give a brief synopsis of Heart of Darkness. This synopsis will make special reference to the two choices in response to the dichotomy of imperialist ideology represented by the managers and Kurtz: hypocrisy and honesty, respectively. Section 4 will compare Mr. Kurtz to the so-called Wildman trope and argue that characterizing Kurtz as belonging to this trope is an oversimplification. The interesting thing about Kurtz is that he actually fails to completely descend to the level of the Wildman and appears to be both an imperialist and a savage - this is what makes him the biggest enemy of imperialist ideology. Section 5 will give a brief synopsis of Apocalypse Now. This synopsis will make special reference to the two choices in response to the dichotomy of imperialist ideology represented by the managers and Kurtz: hypocrisy and honesty, respectively. Section 6 will defend Coppola's interpretation of Kurtz against the charge that it is sexist and not anti-imperialist.

\section{The Dichotomy of Imperialist Ideology and the Choice of the Imperialists}

The dichotomy of imperialist ideology can be well summed up with Nietzsche's old warning: 'Whoever fights with monsters should see to it that in the process he does not become one himself. And if you stare for a long time into an abyss, the abyss stares back into you' (Nietzsche, 1886/2002, p. 69). The imperialist is convinced 
that he is superior to the other. In order to assert this superiority, the imperialist must force the other to submit. Violence is justified in terms of "speaking to the native in a language he understands". The idea is that the natives are so base that the only way to make them understand the superiority of the imperialist is through violence. It is thus seen as a teaching aid. If it is indeed the natives' language then, when the imperialist speaks it better than them, it becomes more the imperialist's language than the natives'. But by this measure the imperialist becomes more like the "inferior" natives. Horror debases those who wield it. Violence is atavistic in the sense that it is supposed to be an animal drive, which civilization defines itself as overcoming. Civilization is supposed to be a social medium through which humans peacefully resolve disputes, through rule of law and social norms and customs based upon dialogue. Only animals and people in a lawless environment are reduced to a "might is right" mentality. The means by which the imperialist must assert his superiority are thus precisely the means by which the imperialist loses his right to claim it. This dichotomy is internal to the logic of imperialist ideology; it functions even on the assumption that violence really is the only language the native understands. As a matter of fact, however, the imperialist has always been fighting monsters of his own imagination. He has made his victims into the monsters he wants them to be in order to legitimize his exploitation of them. If this is so then the real monsters are those that lurk within the imperialist himself and he projects his hate onto his enemy so as not to recognize it in himself. Dialogue is an option the imperialist himself must close off because it admits parity between interlocutors. Hence the absolute fear of contamination, which is a manifestation of the subconscious awareness of imperialist atavism. The imperialist must silence his victims. He must erect barriers to communication and comprehension of his enemy for fear of losing his enemy. Yet doing this is violent, and the more intimately involved with the lives of his victims the imperialist becomes the more savage this violence must be to maintain distance. (This also naturally provokes an escalation of violence on the part of the oppressed in response, which in a perverse way perpetuates the violence of the imperialist by confirming his prejudices). The more savage this violence becomes, the more debased the imperialist becomes.

In response to the dichotomy of the ideology of imperialism there is really only one option for successful imperialists. The violence must be interpreted in a "civilized" way. Either it must utilize the superior technology of the imperialist or it must be rationalized as part of a bureaucratic accounting procedure. This is the path taken by the imperialists at the central station in Heart of Darkness and staff headquarters in Apocalypse Now. These methods are hypocritical attempts to give violence a palatable garb. Violence is violence however it might be interpreted. Kurtz chooses a different option, which exposes the lie of imperialist violence to be base.

\section{Mr. Kurtz in Heart of Darkness}

Heart of Darkness (1899) is a novella by Anglo-Polish novelist Joseph Conrad, written as a frame narrative, about Charles Marlow's experience as an ivory transporter down the Congo River in Central Africa. In Conrad's own words, Heart of Darkness is "a wild story of a journalist who becomes manager of a station in the (African) interior and makes himself worshipped by a tribe of savages. Thus described, the subject seems comic, but it isn't" (Karl \& Davies, 1986, p. 407). Heart of Darkness tells the story of Charles Marlow, an Englishman who took a foreign assignment from a Belgian trading company as a ferry-boat captain in Africa and went in pursuit of this one-time "journalist", the extraordinary and mysterious Mr. Kurtz.

Marlow recounts his mission to recover the manager of the Inner Station after rumours that he has fallen ill. Kurtz is the manager of the Inner Station. This is an esteemed position because it is in an unexplored region, which means first hand access to unexploited territory. This station is very isolated. Kurtz has used his superior technology, exotic appearance, intellect and natural charisma to acquire the reverence accorded a demigod among native Africans in the region of his station. The colloquial English expression to summarise the persona of Kurtz (it should be noted that this expression never occurs in the novel) is that he has 'gone native'. Kurtz has been seduced by the power he can exercise over the natives and has assimilated to local customs and intertribal warfare of the region with the nominal excuse of acquiring ivory.

Everywhere Marlow goes word reaches him of Kurtz, the agent who suddenly tired of life at the colonial Central Station, and struck off on his own into the heart of the Congo. Kurtz was originally an idealistic journalist, and advocate of colonialism. Kurtz leaves because he can no longer stomach the lie of colonialism that enables European traders to pretend that each colonial station "should be like a beacon on the road toward better things, a centre for trade of course, but also for humanizing, improving, instructing" (Conrad, 1989, p. 65) while they routinely engage mass murder for commercial gain. Marlow describes the Company men at the central station as lazy back-biting "pilgrims", fraught with envy and jealousy, all trying to gain a higher status within the Company, which, in turn, would provide more personal profit; however, they sought these goals in a meaningless, ineffective and lazy manner, mixed with a sense that they were all merely waiting, while trying to stay out of harm's way. The pilgrims envy Kurtz' high position and evident superiority. Kurtz is the most productive agent 
in the company. Many in company headquarters hold Kurtz in high regard and predict his rapid promotion. But the pilgrims at the central station closer to Kurtz regard him as a liability and are planning to reprimand him, and it seems have even discussed killing him.

It is, for Kurtz, simply weakness and self-deception to hide one's true motivation behind the trite moralism and meaningless platitudes of the men of the central station. Instead, the authentic response to the "unearthly" and unfamiliar African landscape is to impose one's own will upon it without recourse to moral scruple or empty notions of Enlightenment (p. 69). Only in this way can we confront the inhuman "truth" of the world with our own "true stuff" and create our own laws and values. Marlow is drawn initially to Kurtz's startling renunciation of established truths and values. Kurtz, he believes, "kicked himself free of the earth" because he had the courage to abjure "lies" and self-deceit about the meaning of his actions (p. 57). "There is a taint of death, a flavour of mortality in lies," Marlow reflects "which is exactly what I hate and detest in the world—what I want to forget."

But in consciously abandoning Enlightenment ideals the whole ideological rationale for Kurtz' employment in the Congo drops out and all that is left for him is naked savagery. He becomes an honest imperialist. Kurtz is intoxicated by this newfound moral freedom and power. This no doubt contributes to the sickness that eventually kills him. Despite his enormous success in acquiring ivory, Kurtz' honest approach exposes the hypocrisy of the pilgrims who are disgusted with him. Because of his addiction to the power he enjoys in the jungle Kurtz refuses to leave his station when the opportunity arises and resists the attempts of Marlow and the pilgrims to bring him out. On the return voyage Kurtz seems to try and return to his previous life and begins talking of his career and his fiancé. But Marlow sees through this as just a sham of his previous idealism. Kurtz also sees through it and attempts to escape from the steamship. He is overcome by his illness and dies with the final words "the horror, the horror" an honest recognition of the brutality of the madness of imperialism.

Many historical prototypes for Conrad's Kurtz have been proposed. The broadest consensus is that the closest link is to be found in Belgian officer Léon Rom (although this has been challenged (Warodell, 2015)). Rom was notorious in for decorating his flower garden with the severed heads of his victims on stakes. Adam Hochschild has called this gesture Kurtz's "signal feature" (Hochschild, 1998, p. 145). This savage image is a symbol of the atavism that accompanies renunciation of the modernizing pretense of the ideology of the pilgrims. Peter Edgerly Firchow argued in Rom's defense that 'Hideous, symbolic, and even real as all this is, this [act]...must nevertheless also be viewed and interpreted from the perspective of Central African tribal customs. For in terms of the Congo at the close of the nineteenth century, what Rom did (and Kurtz after him) was entirely in the bounds of privilege accorded to tribal chiefs' (Firchow, 2000, p. 112). This is a mimesis of the African's horror. The reason why the pilgrims are appalled by Kurtz' station is that his method makes it impossible for those who employ it to remain a part of imperial society. Kurtz has abandoned all the restraints and hypocrisies of western civilization. It has brought him the power to obtain great quantities of ivory but it has come at the price of exposing the vulgar greed that underpins the hypocrisies of "respectable" society. The ivory ornaments that were all the rage in the nineteenth century would not look so beautiful if the buyers could see the blood and tears that it took to acquire them. Kurtz' honesty could not be exposed to the European ivory market for this reason. The failure of Kurtz proves that when higher yields are acquired by the imperialist at the price of the illusion of moral superiority the ideological price is too high. Preserving the illusion is, at this level, more valuable than the ivory itself. Kurtz is recalled, and eventually Marlow is sent to capture him, because he is threatening that illusion.

\section{Mr. Kurtz and the Wildman Trope}

Jojada Verrips claims that in Heart of Darkness Kurtz 'the civilized Westerner had fallen back into a savage state....Westerners, just like the so-called savages they turned into their slaves and servants during colonial times, could change into real wild men, and that they possessed a horrifying dark side which under certain circumstances could manifest itself and lead to serious distortions in, as well as of, their environment' (Verrips, 2001, pp. 337-338). The implication is that Kurtz represents something which Western imperialists could become. Verrips does not go into details about what the circumstances might be that effect this transformation, presumably because Heart of Darkness itself is supposed to contain a description of possible dehumanizing circumstances in the Belgian Congo. Nevertheless, Verrips mentions Slavoj Žižek's ideas on fantasy and desire in a conjecture of a possible explanation of the mechanics of this transformation in Kurtz and people like him. The problem with this explanation is that it is based upon the idea that Kurtz has succumbed to something which the imperialists around him have avoided. This is a problematic interpretation because I have already explained the fantasy of the superiority complex of the imperialists, which enables their institutionalized bureaucratic horror in their part of the Ivory trade. Explaining the difference between Kurtz and the other imperialists through fantasy can only appeal to the idea that his fantasy is somehow different from theirs. So now the question should 
be what particular fantasies explain Kurtz's difference from the other imperialists. This question hits the roadblock that there doesn't actually seem to be any fantasies to distinguish Kurtz from the pilgrims. In Marlow's remarks on Kurtz's mastery of rhetoric Kurtz is described as articulating the same imperialist fantasies as the pilgrims with greater eloquence than they. Kurtz is described as actually having seen through the falseness of some of these. Throughout the book Marlow describes Kurtz as superior to his erstwhile colleagues in pretty much every way. The implication of Verrip's explanation is that Kurtz is suffering from some kind of sickness to which the pilgrims find themselves immune. Jiddu Krishnamurti put the issue most succinctly when he said '[i]t is no measure of health to be well adjusted to a profoundly sick society'. These so-called healthy company men have accomplished an industrialized horror on a genocidal scale. The rape of the Congo was accomplished by company men following orders and not by a few isolated eccentric Kurtz characters. These imperialists see Kurtz as a threat to this project. These company men are the banality of evil. Who is sicker than whom: those who employ hypocrisy to demarcate an imaginary boundary in ideology between them and their horror or those who deny this fiction and become their horror simply through an admission of what was already there?

\section{Colonel Kurtz in Apocalypse Now}

Colonel Walter E. Kurtz from the film Apocalypse Now is based on Mr. Kurtz from Heart of Darkness from whom he takes his name. He is also an extraordinary man driven mad by seeing through the lie of the ideology of imperialism. Apocalypse Now is set during the Vietnam War, one of the biggest military adventures of the US Empire of the 20th century. Apocalypse Now follows the central character, Captain Benjamin L. Willard (Martin Sheen), of Military Assistance Command, Vietnam-Studies and Operations Group (MACV-SOG), on a mission to kill U.S. Army Special Forces Colonel Walter E. Kurtz (Marlon Brando) who has gone rogue and is presumed insane. Kurtz has managed to gain admittance into an elite commando division, giving him the independence and resources needed to raise his own army of Montagnard tribesmen. He has conducted high profile and successful operations with increasing independence from MACV. Kurtz employed brutal methods not only in battle but also as psychological warfare. At first MACV didn't object to Kurtz's tactics as they were delivering results. MACV turned against Kurtz when he allowed photographs of his atrocities to be released. Kurtz ignored repeated orders to return to Da Nang and resign his command after he ordered the execution of four South Vietnamese intelligence agents whom he correctly identified as being double agents for the Viet Cong without permission. Kurtz is worshiped by his army as a demi-god and his army have moved through Vietnam, into Cambodia.

After a series of bizarre and harrowing adventures that depict the range of the US army's main modes of violence in Vietnam, Willard finally arrives at Kurtz' base. Willard is overpowered and restrained before being given an audience with Kurtz (Marlon Brando), where Kurtz derides him as an errand boy. Kurtz explains that Willard is working for a bureaucracy that conducts the war as an elaborate accounting exercise as a way of psychologically distancing military command from the horror of its imperial occupation. Eventually Willard is released and given freedom of the compound during which time Kurtz lectures Willard in order to explain himself.

Although Willard acknowledges that Kurtz is insane, these discourses allow Willard some insight into how the hypocrisy of conducting a 'moral' war drove this person, a pure warrior and a moral man, into madness. By fighting an honest war, which does not hide behind the decedent U.S. Empire's illusions of democracy and freedom, quotas and statistics Kurtz has achieved significant military success. But just as with Kurtz from Heart of Darkness, Colonel Kurtz has only achieved this success at the expense of abandoning the rational for the whole enterprise. Kurtz discusses his family and asks that Willard tell his son "the truth" about him in the event of his "death". That night, Willard sneaks into Kurtz' chamber. Kurtz is making a tape recording, in which he is reading, with a tone of indignation, a newspaper article about the U.S. air force command's refusal to allow crews to write obscene words on their planes - a reference to the hypocrisy of the U.S. military's perception of obscenity. Willard mortally wounds Kurtz with a machete. Kurtz, with his dying breath, whispers "...The horror ... the horror ...".

Colonel Kurtz' command was terminated not because he was a bad officer; indeed he was a very excellent and effective officer. Rather, Colonel Kurtz was regarded as a threat by MACV because he exposed the sham of their war. Francis Ford Coppola, the director of Apocalypse Now explained that the primary source for Kurtz' historical significance was the Special Forces Colonel Robert B. Rheault, the actual head of 5th Special Forces Group (May to July, 1969). In 1969 he was arrested for his role in the murder of suspected double agent Thai Khac Chuyen in Nha Trang. The extensive media coverage, of the so-called 'Green Beret Affair' was a source of major embarrassment for the U.S. military, which was portrayed unfavourably as making Rheault into a scapegoat for actions it could not afford to publically condone (Isaacs, 1999). Kurtz did not hide his atrocities (unlike the U.S. army who continue to try and cover up their genocides to this day (Swanson, 2013)) and he did not hide behind the rhetoric of freedom and vocabulary of bureaucracy. Military victory in the Vietnam War 
could not be bought at the price of the USA admitting to itself the greed of its motives and the horror of its methods. The USA could not admit that it was a naked empire exterminating whole nations for the sake of the bank accounts of its $1 \%$. An honest recognition of the systematic and industrialised mass-murder of millions of people in Southeast Asia, many of whom in undeclared wars, most of whom being civilians would be a defeat to the U.S. empire worse than the fumbling slow-motion military defeat in Vietnam and sham legitimacy that the USA actually salvaged from it. Apart from the fact that an honest recognition of its crimes in Southeast Asia, would leave the country open to colossal reparations claims from all of Southeast Asia (Jansen, 2013), enough to bankrupt the USA, an honest recognition would also finally open the U.S empire up to an overwhelming disillusionment with the American Dream. Instead of this, the USA has actually managed to make its victims pay for the war (Chossudovsky, 1995). This is all thanks to the gift of hypocrisy that Kurtz refused.

\section{Is Coppola an Apologist for Imperialism in the Portrayal of Colonel Kurtz?}

Kim Worthy has criticised Coppola's use of the theme of madness in depicting the Vietnam War in Apocalypse Now and particularly Kurz's patriarchal version of it as a sexist whitewashing of the war. Worthy makes this case by radically oversimplifying the meaning of Kurz's self-explanations and then blaming Coppola for her misunderstanding. Worthy uses her interpretation of Kurtz to illustrate her contention that Coppola's depiction of the madness of the Vietnam War is an example of the many U.S. films on this topic that 'accept a mystification of the war which perpetuates the idea that it was part of the human condition' (Worthy, 1996, 157). 'Coppola's version of primitive "contamination"-is obscured history. More specifically, because Apocalypse Now, modelled on Conrad's story, expresses in its narrative structure the masculine hero's fear of self-loss, Coppola's film and Hearts of Darkness also imply that being (mostly white) men a world away from a culture where masculine and white supremacy were natural, drove the military "insane", as Coppola himself expresses it' (Worthy, 1996, p. 158).

Worthy illustrates this point with an analysis of the most famous of Kurtz's speeches to Willard, his so-called "little arms" tale. Kurtz recounts how he was part of a team that went into a village to inoculate the children for polio. After the team's departure, Viet Cong soldiers came into the village and cut off all the children's inoculated arms. Upon being called back to the village Kurtz sees the pile of little arms at which he 'wept like some grandmother'. This has a revelatory affect on Kurtz-'like a diamond bullet'. Kurtz was immediately struck by the idea of the 'genius' of this action. He was overwhelmed by the realisation that his opponents were 'moral and at the same time able to utilize primordial instincts to kill... without judgement.'

Worthy is correct to note the pivotal importance of this speech in explaining Colonel Kurtz. Worthy lumps this anecdote together with scenes of graphic violence in anticommunist propaganda movies from John Wayne's (1968) The Green Beret's to Lawrence D. Folde's (1986) Nightforce, the worn out "escalation of horror" trope. These films are all part of the simplistic black and white ideology of the imperialist, depicting the enemy as a subhuman savage to whom one must show no mercy. Viewers are supposed to share the U.S. soldiers' horror at these atrocities which in these films, strengthens the U.S. soldiers' resolves in fighting the enemy. They function to dehumanise the enemy and inspire fear and loathing of them. Worthy calls the little arms tale a 'sophisticated version' (Worthy, 1996, 158) of this trope. Presumably Worthy thinks it is sophisticated because the affects upon the US soldier in Apocalypse Now is not to strengthen his fighting resolve against the enemy but to lead him down the path of a renegade. So, the psychological affect of this scene upon Kurtz is completely antithetical the affects of "escalation of horror" scenes on other soldiers in propaganda films. This in itself should have set off alarm bells for Worthy that were not heeded. If Kurtz's little arms tale is just another escalation of horror scene then it fails to even pretend to explain his madness, as Worthy claims it does, for such scenes don't send anyone mad in the propaganda films. Something else must have happened.

Worthy's sexual politics reading of such scenes is that they explain the madness of the war, or rather fail to explain it, as subconscious expressions of the male "fear of castration" (Worthy, 1996, p. 160). Worthy describes Colonel Kurtz as disorientated by the apparent transgression of binary sexual boundaries by his enemy. When Kurtz says 'They fought with their hearts' Worthy reads this as implying Kurtz's perception of femininity in the Viet Cong. When Kurtz says that 'they had the strength to do that' Worthy takes this as implying masculinity. This quasi-Freudian essentialist pseudo-explanation prompts Worthy to approvingly quote Frank Tomasulo's criticism: 'By subsuming the Vietnam War under an appeal to the 'primitive' within us all, Apocalypse Now blames everyone (and hence no one) for the policy decisions that created the conflict'. In addition, it suggests that the war was lost because the U.S. was not willing to 'get primitive' enough to exercise its 'will to horror' (even though six times the tonnage of bombs used in World War II were dropped on a country the size of New Mexico)' (Tomasulo, p. 156). I don't see anything sexually charged by Kurtz's remarks to justify Worthy's parallels and I would add to this my suspicion that they are more indicative of Worthy's own sexual prejudices 
than Kurtz's. Worthy seizes the opportunity presented by the confusing sophistication of Kurtz's tale to project her own feminist agenda. Tomasulo's criticism employs the primitive/civilized dichotomy of the imperialist hypocritical ideology of violence it is supposed to be criticising, which Kurtz, at least, has seen through. For while the U.S. army in Vietnam committed atrocities as a matter of routine, they were all sanitised by being framed in statistical game-theory models or covered up and dismissed as aberrations, not the products of sober minds - and often enough as in the case of the My Lai massacre (the tip of the iceberg of U.S. massacres of that kind in that war), they were indeed the paranoid aberrations of a terrified and confused mob of delinquents. This sanitisation of the war was essential for imperialist ideology to keep it going. Neither Kurtz nor Willard could be accused of not noticing the scale of U.S. soldiers' participation in war atrocities. 'Charging a man with murder in this place was like handing out speeding tickets in the Indy 500'. The whole point of Willard's mission to assassinate Kurtz is that he has challenged that ideology, not that he has committed atrocities, but that the way he has committed them could not be hypocritically explained away: 'If that's how Kilgore fought the war, I began to wonder what they really had against Kurtz. It wasn't just insanity and murder, there was enough of that to go around for everyone.'

Tomasulo's interpretation of Kurtz trying to convey the idea that the Viet Cong were more primitive in the horror of their violence completely misses the point Kurtz makes in his final speech about obscenities written on U.S. bomber planes before his assassination as an instance of imperialist hypocrisy enabling the war. Certainly, the imperialists were capable of 'primitive' savagery, but they were not capable of admitting it. This is the whole point. The little arms tale is a description of a premeditated act of mass horror. In its studied precision (they didn't just kill the villagers, they removed the arms which had been inoculated and then gathered them together to make a display) as well as its gore the little arms scene presents a foe which is intimately and directly conscious of its violence and its significance. It is horrific, direct and unambiguously the product of sober minds. There is no attempt to distance the actor from the act as in anonymous bombing campaigns, nor can the act be dismissed as the frenzy of temporary madness brought on by the horror of war. As Kurtz notes it was 'pure'. Kurtz has been overwhelmed by a type of violence that US forces are incapable of consciously recognizing on their own side because of "judgement". Tomasulu implies that U.S. mass bombings were 'primitive' in the incredible, industrialised horror they unleashed upon the Vietnamese, Cambodian and Laotian peoples. Simply equating all violence with the primitive, as Tomasulo has done, is to misperceive the means of imperialist hypocrisy in creating labels for a difference between civilized and primitive violence. While Tomasulo is correct that all violence is atavistic, the imperialist uses the modes of portraying violence through technology, binary opposites, bureaucracy, anomalous frenzy, official secrets and coded language to mediate the experience of violence. While there is no real difference between 'civilized' and 'primitive' violence, there is a difference between imperialist and 'primitive' violence in the realm of ideology. Imperialist violence is dishonest. This difference makes no difference to the victims, but it is an essential component of imperialist ideology and the reason why, amongst other things, the ideals of the anti-war movement ultimately failed in imperialist countries. It is psychologically much easier to press a button to drop a bomb to obliterate a village than it is to systematically cut off the village children's arms. This is one example of the way imperialist ideology exploits the appearance of distance between the actor and the act in industrialised killing to psychologically enable people who aren't really committed to what they are doing to participate in genocide. Kurtz remarks that 'If I had ten divisions of those men [the kind who could perform the little arms massacre], our troubles here would be over very quickly'. But he could never have so many such men without it being a mass movement, with the mass support of the people, people "who fought with their hearts, who had families, who had children, who were filled with love'. These would be people who did not have to mask the true meaning of the horror of the war from themselves and the international community because they acknowledged that it was worth it. But fighting for the Quisling South Vietnamese regime could never be worth it, hence Kurtz's paradox of making a cadre who fights for the subjugation of a people. No cadre could honestly do that. This is how Kurtz has become a nihilist.

\section{Conclusion}

Instead of sanitized civilized violence Kurtz opts for direct violence. He gets his hands dirty. Kurtz refuses to pretend that the civilized violence is any nobler than direct violence. Kurtz calls the so-called civilized interpretation of violence "judgment" which he calls a lie to which we have no moral right. In admitting to himself the true, direct and visceral meaning of his violence, his horror, Kurtz renounces any claims to superiority he might have over his victims/opponents. In this act he has the strange power to become like the natives/enemy. Kurtz can see the horror within him and all of those around him, which enables him to assimilate to a foreign culture through primal mimesis of a basic animal element of all humans. It is in this sense that the imperialist managers are correct to identify Kurtz as becoming a "savage". This is not to denigrate the "savage" 
or imply that the violence of oppressed people is more akin to Kurtz's. This is to admit that Kurtz can relate to people in a basic way, which crosses cultural boundaries. Horror is a universal language even animals understand. Without the straightjacket of layers of ideology to filter his perception of his experiences in the war his natural self has a heightened awareness of the chaos of the war and the natural mimetic response to these circumstances is madness. Kurtz's power of choice paradoxically elevates him above his fellow imperialists, and even above his victims because it seems only he has the strength of will to see his violence for what it truly is. He earns a superior status through renouncing claims to superiority. The only difference between Kurtz and the "civilized" imperialists is that Kurtz sees, whereas they do not, that this is a "difference" which makes no difference. The so-called civilized imperialists are only civilized because they say so. Kurtz does not use labels to hide himself and therefore he exposes the true face of imperialism. He is just as evil but he has the virtue of honesty.

\section{References}

Achebe, C. (2016). An Image of Africa: Racism in Conrad's Heart of Darkness. The Massechusetts Review, 57(1), 14-27. https://doi.org/10.1353/mar.2016.0003

Cahir, L. C. (1992). Narratological Parallels in Joseph Conrad's Heart of Darkness and Francis Ford Coppola's Apocalypse Now. Literature/Film Quarterly, 20(3), 181-187.

Childs, J. (2013). Apocalypse Now, Vietnam, and the Rhetoric of Influence. MATLIT: Materialities of Literature, l(2). https://doi.org/10.14195/2182-8830_1-2_1

Chossudovsky, M. (1995). Who won the Vietnam War? Peace Magazine, Jul-Aug, 6-8.

Conrad, J. (1986). The Collected Letters of Joseph Conrad (Karl, F. R. \& Davies, L. eds., Vol. 2, pp. 1898-1902). Cambridge: Cambridge University Press.

Conrad, J. (1989). Heart of Darkness. London, Penguin.

Coppola, F. F. (Director). (1979). Apocalypse Now [Motion picture]. United States: United Artists.

Eagleton, T. (1976). Criticism and Ideology: A Study in Marxist Literary Theory. London, Verso.

Firchow, P. E. (2000). Envisioning Africa: Racism and Imperialism in Conrad's Heart of Darkness. Lexington: University Press of Kentucky. ISBN 9780813191980.

Hawkins, H. (1982). The Issue of Racism in Heart of Darkness. Conradiana, 14(4), 163-171.

Hoschild, A. (1998). King Leopold's Ghost: A Story of Greed, Terror and Heroism in Colonial Africa. Boston, Mariner Books.

Isaacs, M. (1999). Agent Provocative. SF Weekly.

Janson, J. (2013). In History Reversed, Vietnam's Crimes Against Humanity. In America Would Be Prosecuted, Countercurrents.org. Retrieved April 14, 2013, from https://www.countercurrents.org/janson140413.htm

Nietzsche, F. (1886/2002). Beyond Good and Evil (R.P. Horstmann Ed. \& J. Norman Ed./Trans.). Cambridge: Cambridge University Press. https://doi.org/10.1017/CBO9780511812033

Nixon, R. (1992). London Calling: V. S. Naipaul, Postcolonial Mandarin. Oxford: Oxford University Press. https://doi.org/10.2307/2935128

Swanson, D. (2013). Obama's Campaign to Glorify the war on Vietnam. Retrieved from http://www.globalresearch.ca/obamas-campaign-to-glorify-the-war-on-vietnam/5345739

Tomasulo, F. P. M. (1990). The Politics of Ambivalence: Apocalypse Now as Prowar and Antiwar Film. In L. Dittmar \& G. Michaud (Eds.), From Hanoi to Hollywood: The Vietnam War in American Film. New Brunswick: Rutgers University Press,

Verrips, J. (2001). The Golden Bough and Apocalypse Now: An-other fantasy. Postcolonial Studies, 4(3), 335-348. https://doi.org/10.1080/13688790120102688

Warodell, J. A. (2015). A New Prototype for Kurtz in "Heart of Darkness". Conradiana, 47(3), 239-245. https://doi.org/10.1353/cnd.2015.0027

Watts, C. (2008). Heart of Darkness. In B. Harold (Ed.), Joseph Conrad's Heart of Darkness (pp. 19-37). New York: Infobase Publishing.

Worthy, K. (1996). Emissaries of difference: Conrad, Coppola, and hearts of darkness. Women's Studies: An Inter-Disciplinary Journal, 25(2), 153-167. https://doi.org/10.1080/00497878.1996.9979101 


\section{Copyrights}

Copyright for this article is retained by the author, with first publication rights granted to the journal.

This is an open-access article distributed under the terms and conditions of the Creative Commons Attribution license (http://creativecommons.org/licenses/by/4.0/). 